\title{
$\mathrm{DEA}$ 를 이용한 선박기관 수리기업의 경영 효율성 분석 - 부산 영도구 지역 기관전문수리 기업을 중심으로- \\ 이정필* · 장영수**
}

\section{Measuring Relative Efficiency of Marine Engine Repair Company Using DEA -Specially located in Yeong-Do GU, Busan}

\author{
Jung-Phil Lee* and Young-Soo Jang**
}

\begin{abstract}
The purpose of this study is to present a new business performance model suitable for marin repair business. For this propose we have used survey datas gathered on several input and output factors from Marine engin repair companies Yeong-Do Gu. Gathering these the survey results we estimated the efficiency of each company through DEA method.

The results of the analysis can be summarized as follows ;

First, the result of the analysis showed 7 out of 24 DMU are not efficient companies. On the other hand 17 of them are efficient as the efficient output analyzes showed.

Second, by analysing the results we could see significant differences between group companies, Ltd with a private companies with share on average efficiency in utilization.

Third, two of the private companies are more effective and 6others were selected revisit and interview on the analysis. As a result inefficient DMU compared to efficient DMU and showed that they invest more on manpower in the field of sales and professional managers and techicians. Also, lots of effort devoted in order to standardize production by building capacity and environment management to improve welfare of the workers.
\end{abstract}

Key words : Marin engin agency company, Management efficiency, DEA

접수 : 2012년 9월 6일 최종심사: 2012년 9월 19일게제확정 : 2012년 9월 21일

* 부경대학교 해양산업 경영학과 석사과정(Corresponding author : 051-629-5950,wjdvlf61@naver.com)

** 부경대학교 해양산업경영학과 교수 


\section{I. 서 론}

최근 10 년 간 세계조선시장은 한국과 중국, 일 본 3 국의 경쟁적인 선박 건조기술 발전으로 호 황기를 지나 침체기로 진입하고 있다. 세계 경기 의 불황 또한 선주들에게 부담으로 작용하여 신 조를 회피하게 되고 기존의 선박을 용도에 맞게 개조, 수리하여 유지하려는 성향이 두드러지고 있다. 이와 같은 배경 하에서 아시아국에서는 싱 가포르를 비롯한 중국, 베트남, 중동의 오만까지 도 선박유지에 필수적이라고 할 수 있는 선박수 리분야에 초점을 맞춘 발 빠른 대응으로 수리조 선소를 확충하면서 수요에 대처하고 있다.

우리나라는 대형선, 특수선을 도맡아 수리하 던 미포조선소의 경우, 신조선으로 전환하였고, 실질적 수리조선소 역할을 담당하던 중소조선 소의 연이은 부도로 인해 선박수리는 소형수리 조선업체들이 그 명맥을 유지하고 있는 실정이 다. 이러한 현실은 우리나라를 기항하는 외국선 주가 선박의 개조, 유지, 보수 등을 위해 중국, 베 트남, 싱가포르 등지로 다시 발길을 돌리게 되어 국내 수리조선업체의 경쟁력 약화로 이어지고 있다.

부산항의 글로벌화를 표명하는 부산시 입장 에서도 부산항이 환적 항만으로서 이점을 최대 한 살려 부가가치를 창출하려는 계획에 차질이 생길 수 있다. 부산시는 부산신항의 출범과 함께 새로운 공급사슬을 창출하고자 급유, 선용품, 기 자재, 수리조선 등과 같은 관련 산업 발전을 모 색하였다. 하지만 부산시 발전의 새로운 원동력 으로 육성하고자 하는 부산신항이 항만 공급사 슬의 중요한 구성요소인 수리조선분야가 도태 될 수 있는 위기에 직면할 수도 있는 것이다. 따 라서 경쟁력 있는 수리조선기업 육성은 해운 항 만산업의 선순환적 공급사슬 구축에 있어 대단 히 중요하다고 할 수 있다.

본 연구의 목적은 선박기관 수리기업에 적합 한 새로운 경영성과모형을 제시하는 것이다. 이
를 위해 선박기관 수리기업을 대상으로 효율성 평가인 $\mathrm{DEA}$ 를 이용하여 가장 효율성 있는 업체 를 찾아내고, 이 중 효율성이 높은 업체를 기준으 로 사후분석을 실시하기로 한다. 여기에서 도출 되는 효율성 제고 요인은 경쟁력이 점차 약화되 고 있는 선박기관 수리기업의 경쟁력 향상을 위 한 경영전략요인으로 활용하여 지역 선박기관 수리업체의 발전에 도움을 줄 수 있을 것이다.

본 연구에서는 두 가지 측면에서 연구범위를 제한하고자 한다. 첫 번째는 지리적 범위 제한이 다. 부산은 우리나라 대표적인 수리조선 지역으 로 특히 부산지역을 대표하고 있는 선박기관 수 리업체들의 밀집지역으로는 영도구를 꼽을 수 있다. 영도구는 부산항과 대형 조선소를 중심으 로 자연 발생적으로 형성되면서 현재 부산에서 가장 많은 수의 업체들이 입지해 있다.

두 번째는 연구대상에 대한 제한이다. 한국수 리조선협동조합에 등록되어 있는 업체들은 (1) 선체부와 외관수리를 중심으로 하는 수리조선, (2) 선박엔진, 보일러 등의 수리를 중심으로 하는 선박기관수리, (3) 항해통신, 기관통신 등 통신장 비수리를 중심으로 하는 선박전기전자수리, (4) 냉동선박 전문 수리를 중심으로 하는 선박냉동, (5) 계선, 조타, 항해, 거주지역 등 선박의 여러 설 비 수리를 중심으로 하는 의장수리, (6) 기타수리 로 구분되어 세부 업종별로 나누어져 등록되어 있다. 수리조선업종별로 수리대상이 다르며, 발 생하는 수익의 차이와 공사방식에도 차이가 있 어 동일한 업종인 선박기관 수리업에 한해서 조 사를 실시하였다.

\section{II . 선행연구}

\section{1. 수리조선}

수리조선 산업 관련 선행연구인 부산지역 수 리조선 산업의 현황과 전망(박형호 외, 2003)에 서는 부산지역 내 54 개 주요 수리조선업체를 대 
상으로 경영실태와 영업환경 문제점에 관한 실 태조사를 실시하였다. 조사대상기업의 특성, 경 영실태, 영업환경 및 여건, 클러스터 형성 정도 등에 대한 설문 조사를 실시한 결과, 한국 수리 조선시장 여건악화, 중국과의 경쟁심화, 낮은 생 산성, 취약한 업무환경 등의 문제점을 안고 있는 것으로 나타났다. 이에 대해 정부지원책, 제고 노력 강화, 업무방식의 효율성, 저변확대, 대상 선박 다변화 발전방안 등을 제시하였다.

신용존(2007)의 연구에서는 부산의 수리조선 산업을 중심으로 부산신항만 발전 모델 구축 방 안을 제시하였다. 여기에서는 신항의 고부가가 치 항만으로 발전방안과 국내외 경쟁력, 자생력 방안으로 수리조선 산업이 대안임을 제시하면 서 이를 근거로 부산지역 현황에 대해 분석하고 실태조사를 실시하였다.

김성태(2009)는 부산지역 수리조선업의 실태 및 문제점 그리고 수요자인 해운회사 및 아시아 지역 주요 수리조선소의 특성을 분석하였다. 이 를 바탕으로 국제경쟁력을 결정하는 평가항목 을 추출하여 퍼지계층분석(AHP)을 활용하여 부 산, 중국 및 싱가포르를 대상으로 종합적인 경쟁 력 평가 및 경쟁력 강화방안을 제시하면서 동시 에 선택 가능한 대안에 대해 검토하였다. 이러한 분석 및 검토결과를 바탕으로 기반시설 및 기술 수준, 비용, 서비스 수리기간 및 입지에 대하여 구체적인 방안을 강구하고 있다.

서무천(2010)의 연구에서는 전남지역의 수리 조선 산업과 부산지역의 수리조선소의 경쟁력 을 비교하면서 전남지역의 수리조선기업의 경 제효과를 근거로 수리조선 산업이 지역경제에 중요한 산업임을 강조하고 있다. 또한 수리조선 의 수요에 대해 구체적 근거를 제시하면서 환경 적 측면, 입지여건, 임금, 기술적 측면에서의 경 쟁력을 중심으로 수리조선산업 진출의 타당성 을 외국의 예와 비교분석하였다. 그 밖에도 다수 의 논문에서 현황과 실태파악 후 수리조선 산업 을 신조선에 대한 대안적 산업 또는 지역발전 산
업으로 제시하고 있다.

본 연구에서는 산업 현황분석을 통한 대안제 시의 형식에서 탈피하고 기업 실태조사를 실시 하여 본질적인 기업내부 경영구조를 파악하는 데 연구의 초점을 두고 있다.

\section{DEA}

$\mathrm{DEA}$ 관련 선행연구는 상당히 많이 이루어지 고 있다. 김강정(2005)은 우리나라 멀티플렉스 산업의 효율성을 분석하면서 투입변수로 직원 수, 총 자산, 매출원가를 선정하였고, 산출변수 로는 매출액을 선정하여 멀티플렉스 업체별 상 대적 효율성을 평가하였다.

$\mathrm{DEA}$ 를 이용한 $\mathrm{BSC}$ 기반의 은행지점 효율성 평가에 관한 최민영(2008)의 연구에서는 BSC기 반의 은행지점 효율성을 산출기준으로 평가하 였다. 여기에서는 3 단계에 걸친 투입변수로 (1) 연수 참가노력도, 직원실무평가, 부점 자율연수 참여도, (2) 준법감시 및 사고 예방, 협력마케팅, 기반확대 수수료, 경영현안지표, (3) 우량고객유 치, 고객만족도, $\mathrm{CIF}$ 정비율로 설정하고, 산출변 수 또한 3 단계에 걸쳐 (1) 준법감시 및 사고예방, 협력마케팅, 기반확대수수료, 경 영현안지표, (2) 우량고객유치, 고객만족도, $\mathrm{CIF}$ 정비율, (3) 충당 금 차감 후 이익, 대출연체관리, 총대출금 증가 액, 총 수신증가액, 수수료기반 조성을 선정하여 성과평가 기반에서 지점의 효율성 측정을 위해 3 단계에 걸친 효율성 측정 모형을 제시하여 은 행의 전반적인 효율성을 측정하였다.

특급호텔 외식사업부의 경영효율성에 관한 배준호(2010)연구는 방법론적으로 다수의 투입 과 산출요소를 갖는 서비스 기업의 효율성 평가 에 DEA 모형을 활용하여 효율성 평가를 실시하 였다. 투입변수로는 고객 수, 좌석 수, 종업원 수, 인건비, 면적으로 선정하고 산출변수로는 매출 액, 순이익으로 선정, DEA 결과를 활용하여 Tobit분석을 실시하였다.

정성민 외(2010)의 연구에서는 방위산업체의 
효율성 및 생산성 분석을 위하여 투입변수로는 종업원 수, 총 자산, 재료비를 선정하고 산출변 수로는 매출액을 선정하여 방위산업체의 상대 적 효율성을 평가하고, Malmquist 생산성 지수 를 활용한 시계열 분석을 실시하여 동적인 효율 성의 측면을 파악하였다.

한편, 이상에서 언급한 선행연구에서 참조하 였던 은행, 호텔, 군대, 방위산업체 등 대표적 공 공기관을 대상으로 한 선행연구에서도 확인하 였듯이 경영 효율성 분석에 사용되는 공통 변수 는 본 연구에서도 적용하기로 한다.

본 연구에서는 델파이 방법으로 전문가 의견 종합과 추정과정을 거쳐 수리조선분야의 보다 실천적이고 실태에 반영될 수 있는 변수를 선정 하고 추가분석하기로 한다.

\section{III. 선박기관 수리기업 현황 및 연구설계}

\section{1. 선박기관 수리기업 현황}

선박기관 수리업은 수리조선 산업의 일종으 로 선박의 개조 - 보수 · 정비 등을 수행하는 산 업 활동 중 선박의 기관(엔진, 보일러, 축계 등) 을 전문적으로 수리하는 조선 산업의 세부업종 중 하나인 선박기관 수리업을 말한담. 통계청 의 한국표준산업분류에 의하면 수리조선 산업 은 제조업과 수리업으로 구분된다.
선박기관 수리기업은 수리조선 산업(표준산 업분류 : 95119)의 하위산업 중 선박의 기관을 수리하는 기업을 지칭하고 있다. 부산에 위치한 수리조선관련 기업의 수는 2009년 전국사업체 조사 9차 계정에 따르면 933개에 달하고 있고, 이들 중 선박의 기관을 전문적으로 수리하는 곳 은 197 개 업체에 달하는 것으로 나타났다.

〈표 1〉은 부산지역 수리조선 관련 기업현황 을 정리한 것이다. 한국선박수리공업 협동조합 에 2011년 기준으로 등록되어 있는 483개의 업 체 중 업종을 수리조선으로 다루고 있는 82 개의 업체는 주로 선체부, 외관수리를 담당하고 있으 며, 선박기관 수리는 업종분류 중 가장 많은 197 개 업체로 선박의 엔진, 보일러, 축계 등을 전문 적으로 수리하고 있다. 그 외 선박전기전자의 업 종으로 분류되어 있는 64 개의 업체는 항해통신, 기관통신, 항해통신장비 수리를 주요 업무로 하 고 있으며, 선박의 냉동과 관련된 17 개 업체, 선 박의 여러 설비 즉, 계선, 조타, 항해, 거주시설, 창고, 통풍 등을 주요업무로 하는 의장수리 업체 가 10 개, 기타 가바나, 크레인, 자이로, 닺 등을 전문적으로 수리하는 기타업체 113 개가 회원이 다. 조합 통계상 이들 중 타 지역(시, 구, 군)을 주 소로 등록하고 있는 183 개의 업체를 제외하고는 $62 \%$ 에 해당하는 300 개의 업체가 영도구에서 영 업 중이다.

〈표 1 〉부산 지역 수리조선 관련 기업 현황

\begin{tabular}{|c|c|c|}
\hline 업 종 & 세부업체 수 & 주요 업무 \\
\hline 수리조선 & 82 & 선체부, 외관수리 \\
\hline 선박기관수리 & 197 & 선박의 엔진, 보일러, 축계 등을 전문적으로 수리 \\
\hline 선박전기전자 & 64 & 항해통신, 기관통신, 항해통신장비 수리 \\
\hline 선박냉동 & 17 & 냉동선박 전문(바나나, 수산물 운반선 등) \\
\hline 의장수리 & 10 & 선박의 여러 설비 즉, 계선, 조타, 항해, 거주, 창고, 통풍 $\cdots$ \\
\hline 기타 & 113 & 가바나, 크레인, 자이로, 닻 등 \\
\hline 합계 & 483 & \\
\hline
\end{tabular}

자료 : 한국선박수리공업 협동조합(2011)

1) 신용존(2007) 
한국선박수리공업 협동조합에 가입되어 있는 업체 중에서는 세관신청서 업무를 위해 많은 선 용품업체나 기자재업체들과 함께 등록이 되어 있으며, 영도구에서 영업 중인 수리조선 업체 중 에서도 조합에 가입이 되어 있지 않은 업체가 많 이 있는 것으로 조사되었다.

영도구에 위치하고 있는 수리조선업체들은 주로 남항동, 대평동, 봉래동, 청학동을 중심으 로 산재해 있다. 남항과 입지적으로 가깝고 중소 형 조선소들이 입지해 있어 어선수리가 활발한 대평동, 남항동일 대와 한진중공업을 중심으로 산업단지로 조성된 청학동, 봉래동 일대에 주로 분포하고 있다. 본 연구에서 분석대상으로 하고 있는 선박기관 수리기업은 영도구에 위치한 선 박수리기업 중 선박기관 수리를 전문적으로 하 고 있고 한국선박수리공업 협동조합에 등록되 어 있는 업체를 대상으로 한정하기로 한다.

\section{2. 변수 설정}

산업 특성이 반영된 변수도출을 위해 2011년 10 월 한달간 대상 업체 직접방문조사를 통한 전 문가와의 심층분석, 경력 8 년 이상의 업체 대표
자 6명과의 $\mathrm{FGI}($ 표적집단면접법)를 통해 경력, 주거래 업체수, 인건비, 공장규모, 연간 수리건 수, 확보된 전문 기술자수, 기업형태, 연매출액, 월별 재료구입비, 인력수급, 고정자산, 대금결제 기간 등의 총 14 개의 변수를 선정하였다.

변수 선정 후에는 이 변수를 조절 가능한 변수 와 조절 불가능한 변수로 나누고, 최종 변수 선 정에서는 생산 함수인 Cobb-Douglas 생산함수 를 고려하였다.

기업은 자본(K)과 노동(L)을 투입하여 제품을 만들고 그것을 판매하여 매출액 $(\mathrm{Y})$ 이 결정된다. 여기에서 기업의 자본 규모는 회사의 총 자산으 로 판단할 수 있으나 개별 경영자료 획득의 어려 움으로 공장규모로 대신하였다. 제품을 생산하 기 위해 필요한 중간재는 재료구입비로 설명될 수 있고, 노동 규모는 실제 제품을 생산하는데 종사하고 있는 종업원 수로 결정될 수 있지만 제 품의 생산이 아닌 전문 수리기술을 필요로 하는 업종이므로 차별을 두기 위해 전문 기술자로 제 한하여 조정 하였다.

나머지 인력수급과 대금결제기간, 업체위치, 생산표준화 등은 운영능력 비교를 위해 추가로

〈표2〉변수설정

\begin{tabular}{|c|c|c|c|c|}
\hline 구 분 & 변 수 & 자원분류 & 변수 분류 & 세부사항 \\
\hline 1 & 경력 & 조절 불가능한 변수 & - & 운영능력 비교 \\
\hline 2 & 주거래 업체 수 & 조절 불가능한 변수 & - & 운영능력 비교 \\
\hline 3 & 인건비 & 조절 불가능한 변수 & 투입변수 & - \\
\hline 4 & 공장규모 & 조절 가능한 변술) & 투입변수 & - \\
\hline 5 & 연간 수리건 수 & 조절 불가능한 변수 & - & 운영능력 비교 \\
\hline 6 & 확보된 전문 기술자 수 & 조절 가능한 변수 & 투입변수 & - \\
\hline 7 & 기업형태 & 조절 불가능한 변수 & - & 기업분류, 그룹핑 \\
\hline 8 & 연 매출액 & 조절 불가능한 변수 & 산출변수 & - \\
\hline 9 & 월 별 재료구입비 & 조절 불가능한 변수 & 투입변수 & - \\
\hline 10 & 고정자산 & 조절 가능한 변수 & - & - \\
\hline 11 & 인력수급 & - & - & 운영능력 비교 \\
\hline 12 & 대금결제기간 & - & - & 운영능력 비교 \\
\hline 13 & 업체위치 & - & - & 업체위치 비교 \\
\hline 14 & 생산표준화 & - & - & 운영능력 비교 \\
\hline
\end{tabular}

2) 조절 가능한 변수는 가공이 가능하거나 대체 가능한 것을 뜻한다. 
조사하였다. 이를 통해 최종적으로 선정된 변수 들을 투입변수와 산출변수로 구분하였는데 투 입변수에는 인건비, 공장규모, 전문기술자 수, 월별 재료구입비로 선정하였고, 산출변수로는 연매출액을 선정하였다〈표 2〉.

전문 기술자 수는 일용직 근로자가 아닌 정규 직 기술자를 뜻하며 전문적인 기술직을 뜻하고 있다. 공장규모는 업체가 소유하고 있는 공장의 평 $\left(\mathrm{m}^{3}\right)$ 으로 나타내어 조사하였고, 인건비는 월 별 인건비 총액으로, 월별 재료비는 월별 고정적 으로 수리하는데 소요된 재료비를 선정하여 조 사하였다. 산출변수로는 연간매출액으로 연간 업체의 선박기관수리 총 매출액을 나타내었다

〈표 3〉.

〈표 3 〉변수의 조작적 정의

\begin{tabular}{|c|c|c|}
\hline 구 분 & 주요변수 & 변수의 설명 \\
\hline \multirow{4}{*}{ 투입변수 } & 기술자 수 & $\begin{array}{l}\text { 선박기관 수리업에 종사하는 } \\
\text { 기술자의 수 }\end{array}$ \\
\hline & 공장규모 & $\begin{array}{l}\text { 업체가 소유하고 있는 공장의 } \\
\text { 규모(평) }\end{array}$ \\
\hline & 인건비 & 월별 인건비 총액 \\
\hline & 재료비 & 수리하는데 소요된 재료비 \\
\hline 산출변수 & 연간 매출액 & $\begin{array}{l}\text { 연간 업체의 선박기관수리 총 } \\
\text { 매출액 }\end{array}$ \\
\hline
\end{tabular}

\section{3. 조사방법}

조사대상은 부산시 영도구 일대 선박기관수 리 업체 140 여 업체로, 이들 중 업태가 기관 수리 로 등록이 되어 있는 업체(전문 엔진 수리업체) 이다. 선박수리 협동조합에 가입되어 있고, 사업 장이 영도구 남항동, 대평동, 대교동, 청학동, 봉 래동에 위치해 있으며, 업체가 공장을 소유하고 있는 형태의 업체를 모집단으로 선정하였다.

설문조사 대상 총 58 곳 중 부재중이거나 응답 을 회피한 25 곳을 제외한 총 33 곳의 업체를 설문 조사하였다. 응답내용이 부실한 9개 업체를 제 외한 최종 유효응답 설문지 24 부를 분석에 사용 하였다.
지역적으로 대평동에 입지한 기업이 10 곳, 남 항동 9곳, 청학동 4 곳, 봉래동 1 곳으로 나타났으 며, 분야별로 고속엔진과 저속엔진을 모두 취급 하는 곳이 13 곳, 저속엔진전문업체가 8 곳, 고속 엔진전문업체가 3 곳으로 나타났다. 업체의 유형 별로는 주식업체가 8 곳, 개인 업체가 16 곳으로 나타났다〈표 4〉.

〈표 4 〉응답자의 특성

\begin{tabular}{|c|c|c|c|}
\hline \multicolumn{2}{|c|}{ 구 분 } & 빈도 & 비 율 $(\%)$ \\
\hline \multirow{4}{*}{ 지 역 } & 남 항 동 & 9 & $37.50 \%$ \\
\hline & 대 평 동 & 10 & $41.67 \%$ \\
\hline & 청 학 동 & 4 & $16.67 \%$ \\
\hline & 봉 래 동 & 1 & $4.17 \%$ \\
\hline \multirow{3}{*}{ 전문분야 } & 고속엔진전문 & 3 & $12.50 \%$ \\
\hline & 저속엔진전문 & 8 & $33.33 \%$ \\
\hline & 고속+저속 & 13 & $54.17 \%$ \\
\hline \multirow{2}{*}{ 업체유형 } & 주식업체 & 8 & $33.33 \%$ \\
\hline & 개인업체 & 16 & $66.67 \%$ \\
\hline
\end{tabular}

자료 수집은 구조화된 설문지를 사용하였고, 2011년 10월21일부터 2011년 11월 3일까지 방문 면담조사를 실시하였으며, 조사내용은〈표 5〉 와 같다. 업체의 경력 및 업체규모 조사를 위해 공 장의 규모, 회사의 형태, 종업원 및 순수 기술자 수와 업체별 자본 조사를 위해 연간 매출액, 고정 자산 구입총액, 재료 및 재화구입비, 인건비 총액 을 조사하였다. 주거래 업체수 및 연간 수리건수 를 사후분석 비교대상의 변수로 조사하였다.

$\langle$ 표 5 〉조사내용

\begin{tabular}{l|l}
\hline \multicolumn{1}{c|}{ 구 분 } & \multicolumn{1}{c}{ 조 사 내 용 } \\
\hline $\begin{array}{l}\text { 업체의 경력 및 } \\
\text { 업체규모 조사 }\end{array}$ & $\begin{array}{l}\text { 공장의 규모, 회사의 형태, 종업원 } \\
\text { 및시룰자 수 }\end{array}$ \\
\hline 업체별 자본 조사 & $\begin{array}{l}\text { 연간 매출액, 고정자산 구입총액, } \\
\text { 재료 및 재화 구입비, 인건비 총액 }\end{array}$ \\
\hline 기타조사 & 주거래 업체 수 및 연간 수리건 수 \\
\hline
\end{tabular}

\section{4. 변수의 기술 통계학적 특성}

변수의 특징 중 먼저 투입변수를 살펴보면 기 술자수는 평균 7.71명으로 제조업 평균의 9명에 
$\mathrm{DEA}$ 를 이용한 선박기관 수리기업의 경영 효율성 분석 - 부산 영도구 지역 기관전문수리 기업을 중심으로 -

〈표 6〉변수의 특징

\begin{tabular}{|c|c|c|c|c|c|c|}
\hline \multirow{2}{*}{\multicolumn{2}{|c|}{ 업체명 }} & \multicolumn{4}{|c|}{ 투입요소 } & 산출요소 \\
\hline & & \multirow{2}{*}{$\begin{array}{c}\text { 기술자수 } \\
\text { 명 }\end{array}$} & \multirow{2}{*}{$\begin{array}{c}\text { 공장규모 } \\
\text { 평 }\end{array}$} & \multirow{2}{*}{$\begin{array}{c}\text { 인건비총액(월) } \\
\text { 원 }\end{array}$} & \multirow{2}{*}{$\begin{array}{c}\text { 월별 재료 및 } \\
\text { 재화구입비 } \\
\text { 원 }\end{array}$} & \multirow{2}{*}{$\begin{array}{c}\text { 연간매출액 } \\
\text { 원 }\end{array}$} \\
\hline 단위 & 회사형태 & & & & & \\
\hline DMU1 & 주식 & 20 & 250 & $120,000,000$ & $450,000,000$ & $10,000,000,000$ \\
\hline DMU2 & 개인 & 5 & 40 & $20,000,000$ & $15,000,000$ & $1,500,000,000$ \\
\hline DMU3 & 개인 & 2 & 40 & $4,000,000$ & $5,000,000$ & $100,000,000$ \\
\hline DMU4 & 주식 & 5 & 150 & $22,000,000$ & $85,000,000$ & $3,700,000,000$ \\
\hline DMU5 & 개인 & 3 & 36 & $30,000,000$ & $40,000,000$ & $700,000,000$ \\
\hline DMU6 & 주식 & 25 & 407 & $1,000,000,000$ & $500,000,000$ & $20,500,000,000$ \\
\hline DMU7 & 개인 & 7 & 50 & $20,000,000$ & $5,000,000$ & $1,500,000,000$ \\
\hline DMU8 & 개인 & 8 & 70 & $40,000,000$ & $3,000,000$ & $2,800,000,000$ \\
\hline DMU9 & 주식 & 10 & 70 & $62,000,000$ & $50,000,000$ & $3,000,000,000$ \\
\hline DMU10 & 개인 & 5 & 60 & $20,000,000$ & $3,000,000$ & $1,000,000,000$ \\
\hline DMU11 & 개인 & 2 & 20 & $12,000,000$ & $2,500,000$ & $300,000,000$ \\
\hline DMU12 & 주식 & 3 & 123 & $15,000,000$ & $20,000,000$ & $3,000,000,000$ \\
\hline DMU13 & 주식 & 56 & 2000 & $400,000,000$ & $100,000,000$ & $20,000,000,000$ \\
\hline DMU14 & 개인 & 4 & 50 & $50,000,000$ & $8,000,000$ & $1,500,000,000$ \\
\hline DMU15 & 주식 & 4 & 40 & $50,000,000$ & $8,000,000$ & $2,000,000,000$ \\
\hline DMU16 & 개인 & 3 & 35 & $5,000,000$ & $2,500,000$ & $220,000,000$ \\
\hline DMU17 & 개인 & 4 & 60 & $13,000,000$ & $40,000,000$ & $1,100,000,000$ \\
\hline DMU18 & 개인 & 4 & 120 & $20,000,000$ & $85,000,000$ & $2,000,000,000$ \\
\hline DMU19 & 개인 & 4 & 130 & $13,000,000$ & $100,000,000$ & $1,400,000,000$ \\
\hline DMU20 & 개인 & 2 & 65 & $15,000,000$ & $30,000,000$ & $600,000,000$ \\
\hline DMU21 & 개인 & 1 & 50 & $2,500,000$ & $20,000,000$ & $1,000,000,000$ \\
\hline DMU22 & 주식 & 3 & 223 & $120,000,000$ & $120,000,000$ & $3,500,000,000$ \\
\hline DMU23 & 개인 & 2 & 99 & $7,000,000$ & $10,000,000$ & $700,000,000$ \\
\hline DMU24 & 개인 & 3 & 75 & $15,000,000$ & $5,000,000$ & $1,000,000,000$ \\
\hline \multicolumn{2}{|c|}{ 평 균 } & 7.71 & 177.625 & $86,479,166.70$ & $71,125,000$ & $3,463,333,333$ \\
\hline \multicolumn{2}{|c|}{ 표준편차 } & 11.43 & 397.601381 & $210,880,271$ & $101,747,923$ & $5,364,863,071$ \\
\hline \multicolumn{2}{|c|}{ 최 대 } & 56 & 2000 & $1,000,000,000$ & $500,000,000$ & $20,500,000,000$ \\
\hline \multicolumn{2}{|c|}{ 최 소 } & 1 & 20 & $2,500,000$ & $2,500,000$ & $100,000,000$ \\
\hline
\end{tabular}

못 미치는 수준으로 나타날 수 있으나 순수 기술 자를 나타내는 숫자이므로 고용지수는 비슷하 거나 더 높을 수 있다. 공장규모는 평균 177.6 평, 인건비 총액은 월평균 $86,479,166$ 원, 재료 및 재 화구입비는 월평균 $71,125,000$ 원으로 나타났다. 산출변수인 연간매출액은 업체 연 평균 $3,463,333,333$ 원으로 나타났다. 한편, 기업 간의 표준편차가 크게 나타난 이유로는 업체별 규모
차이와 신생기업 등이 분포하고 있기 때문이다. 조사대상 중 주식회사는 DMU1을 포함한 4,6 , $9,12,13,15,22$ 로 총 8 개 기업이 주식회사였으 며, 나머지 16 개 기업이 개인회사의 형태였다.

\section{5. 연구모형}

연구 모형은 아래 〈그림 1〉 과 같다. 우선 전 문가 집단과의 $\mathrm{FGI}($ 표적집단면접법)를 통해 선정 


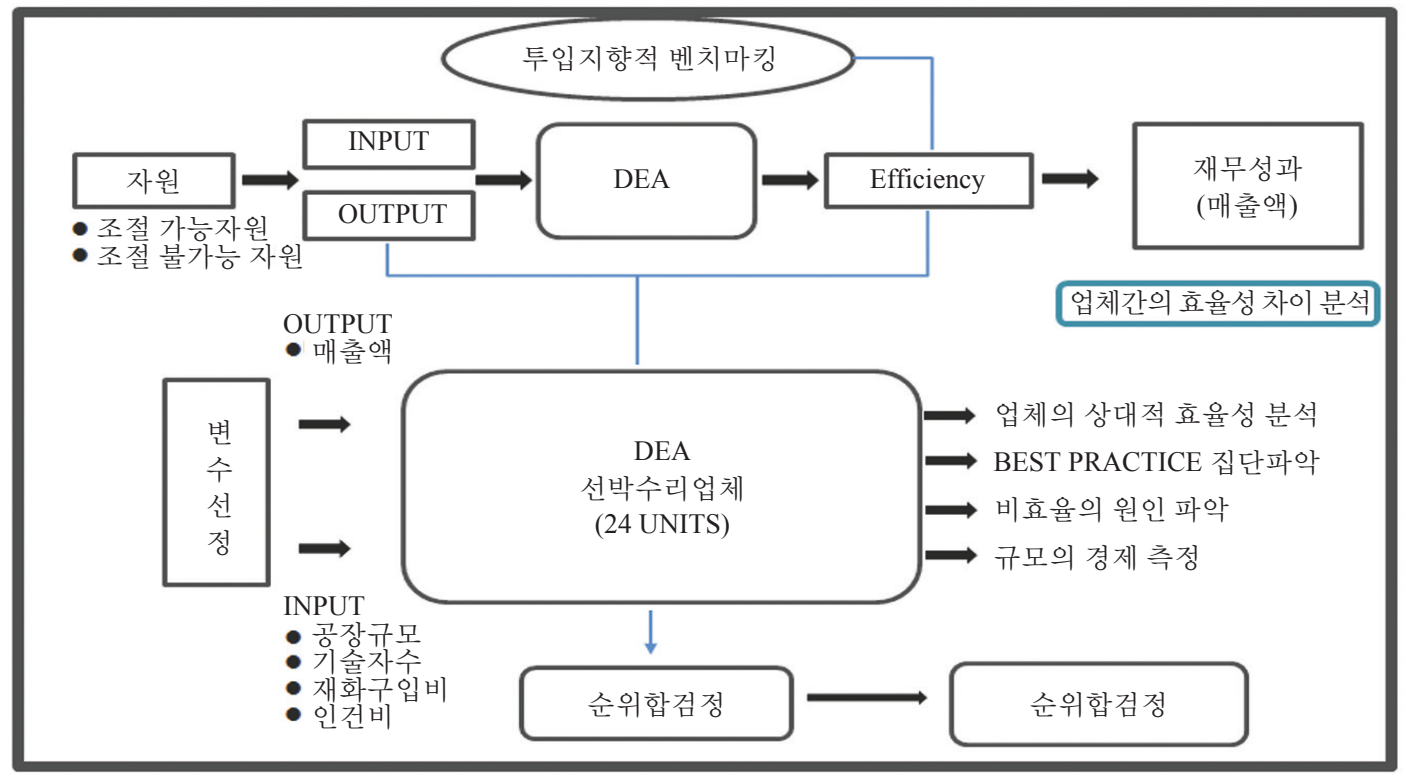

〈그림 1〉 연구모형

된 14 개의 변수를 조절 가능한 자원과 조절 불가 능한 자원으로 나누어 최종적으로 투입요소와 산 출요소로 구분하고 DEA모형을 사용하여 경영효 율성을 측정하기로 한다. 이를 통해 업체의 상대 적 효율성을 분석하고 효율적으로 나타난 집단과 비효율적으로 나타난 집단의 차이를 규명하기로 한다. 또한 두 그룹 간의 효율성 차이가 유의한지 여부를 검증하기 위해 DEA모형의 결과에 대해 순위합 검정을 실시하고 이를 토대로 표본을 그 룹핑하여 사후분석을 실시한다. 이는 비효율적으 로 나타난 기업과 효율적으로 나타난 집단의 표 본을 무작위로 선정하고 두 그룹을 비교분석하여 실증적인 원인을 찾고자 하는데 있다.

\section{IV . 경영 효율성 분석 결과}

\section{DEA 분석결과}

선박 수리업체의 DEA 분석결과는 〈표 7〉과 같다. TE는 기술 효율성, PTE는 순수기술효율성, $\mathrm{SE}$ 는 규모의 효율성, $\mathrm{CRS}$ 는 규모의 경제성, $\mathrm{DRS}$ 는 규모의 수익체감, IRS는 규모의 수익체
증을 뜻한다.

분석결과, DMU 1, 6, 8, 12, 15, 21, 22 총 7개 업 체가 효율적인 업체로 평가되었으며, 이에 비해 DMU 2를 포함한 나머지 17개 업체가 비효율적 인 업체로 분석되었다. DMU $2,3,4,7,11,13$, 16,24 의 경우, $\mathrm{PTE}$ 값은 ' 1 '인 반면, $\mathrm{SE}$ 값은 ' 1 ' 이하로 규모의 비효율성이 발생하고 있다.

이 업체들 중 DMU 4와 13 을 제외한 나머지 업 체의 경우, 규모수익이 IRS상태로 분석됨에 따 라 규모의 경제 실현을 통해 경영효율성 향상 및 매출액 상승을 기대할 수 있다.

반면, DMU 9의 경우, SE 값이 PTE 값보다 상 대적으로 높고, 규모수익이 DRS 상태로 분석됨 에 따라 업체의 규모 확대보다는 신기술 도입 및 투입요소의 경영개선을 통해 업체의 효율성을 높여나가야 할 것이다. 참조횟수를 분석해보면 참조 횟수가 높다고 해서 가장 효율성이 높은 업 체라고 평가할 수는 없다. 하지만 준거집단은 투 입요소 및 산출요소의 조합에 있어서 비효율적 인 기관들이 벤치마킹의 대상으로 삼아야 할 기 관이라는 점에서 중요하다. 분석결과에 따르면 
$\mathrm{DMU} 11$ 과 21이 참조 횟수가 가장 많은 업체로 분석되었다. 그 외 참조집단이 높은 $\mathrm{DMU}$ 를 살 펴보면, DMU 11을 제외한 나머지 업체인 DMU $1,8,12,21$ 등은 개인회사 3 개와 주식회사 3 개로 나타나 개인회사와 주식회사들이 DEA모형의 프론티어를 같이 형성하고 있을 것으로 추측가 능하다.

한편, 투입요소가 다른 업체들보다 월등히 높 은 투입요소 상위 4 개 DMU $1,6,13,22$ 를 살펴 보면 모두 주식회사이다. DMU 1과 6, 22는 투입 요소 투입치가 상대적으로 높으며, 산출요소인
연간 매출액 또한 평균에 비해 월등히 높은 것을 〈표 7〉에서 확인할 수 있다. 결과 또한 규모의 효율성을 달성하고 있는데 반해 DMU 13 의 경 우에는 전체 $\mathrm{DMU}$ 중 기술자수 1 위, 공장규모 1 위, 인건비 총액 2 위, 월별 재료 및 재화구입비 4 위, 연간 매출액 2위로 나타나 DMU 1과 비교하 여 투입요소 투입치에 비해 매출액이 적은 것이 규모수익 체감으로 나타난 원인이다.

규모수익체감으로 나타난 DMU 4, 9, 13 의 경 우 위와 마찬가지로 주식회사의 형태를 띄며, 투 입요소 면에서 과잉투자되어 있는 현실을 반영

〈표 7〉 선박기관 수리업체의 DEA 분석결과

\begin{tabular}{|c|c|c|c|c|c|c|}
\hline DMU & TE(CRS) & PTE(VRS) & SE(IRS) & 규모수익 & 준거집단 & 참조횟수 \\
\hline DMU1 & 1 & 1 & 1 & CRS & 1 & 3 \\
\hline DMU2 & 0.9844 & 1 & 0.9844 & IRS & 2 & 1 \\
\hline DMU3 & 0.1306 & 1 & 0.1306 & IRS & 3 & 1 \\
\hline DMU4 & 0.9685 & 1 & 0.9685 & DRS & 4 & 0 \\
\hline DMU5 & 0.4494 & 0.7547 & 0.5955 & IRS & $11,15,21$ & 0 \\
\hline DMU6 & 1 & 1 & 1 & CRS & 6 & 1 \\
\hline DMU7 & 0.8806 & 1 & 0.8806 & IRS & 7 & 0 \\
\hline DMU8 & 1 & 1 & 1 & CRS & 8 & 2 \\
\hline DMU9 & 0.9506 & 0.9656 & 0.9845 & DRS & $1,6,8,15$ & 0 \\
\hline DMU10 & 0.6431 & 0.8819 & 0.7292 & IRS & $8,11,16$ & 0 \\
\hline DMU11 & 0.3816 & 1 & 0.3816 & IRS & 11 & 6 \\
\hline DMU12 & 1 & 1 & 1 & CRS & 12 & 4 \\
\hline DMU13 & 0.7204 & 1 & 0.7204 & DRS & 13 & 0 \\
\hline DMU14 & 0.7406 & 0.8346 & 0.8874 & IRS & $11,12,15$ & 0 \\
\hline DMU15 & 1 & 1 & 1 & CRS & 15 & 4 \\
\hline DMU16 & 0.3863 & 1 & 0.3863 & IRS & 16 & 1 \\
\hline DMU17 & 0.6428 & 0.7259 & 0.8855 & IRS & $2,11,21$ & 0 \\
\hline DMU18 & 0.6328 & 0.6522 & 0.9703 & IRS & $1,12,15,21$ & 0 \\
\hline DMU19 & 0.4672 & 0.4774 & 0.9786 & IRS & $1,12,21$ & 0 \\
\hline DMU20 & 0.3459 & 0.64 & 0.5405 & IRS & 11,21 & 0 \\
\hline DMU21 & 1 & 1 & 1 & CRS & 21 & 6 \\
\hline DMU22 & 1 & 1 & 1 & CRS & 22 & 0 \\
\hline DMU23 & 0.493 & 0.9577 & 0.5148 & IRS & $3,11,12,21$ & 0 \\
\hline DMU24 & 0.6895 & 1 & 0.6895 & IRS & 24 & 0 \\
\hline 평균 & 0.6635 & 0.8973 & 0.7394 & & & \\
\hline 표준편차 & 0.2646 & 0.1469 & 0.2472 & & & \\
\hline 최대값 & 1 & 1 & 1 & & & \\
\hline
\end{tabular}


이정필 · 장영수

하고 있다고 볼 수 있다. 이를 위해 각각의 DMU 는 투입요소의 규모축소 및 통제에 노력하는 것 이 규모수익체감을 극복하는 방안으로 제시될 수 있다.

모든 $\mathrm{DMU}$ 들에 대한 규모수익가변 상황하의 효율성 평가 결과, 평가 대상 업체 중 규모수익 불변(CRS)인 업체가 7 개(29\%), 규모수익체감 (DRS)인 업체가 3 개( $12.5 \%)$, 규모수익체증(IRS) 인 업체가 14 개 $(58.3 \%)$ 로 분석되었다. 평균값을 살펴보면, 기술효율성은 0.6635 , 순수기술 효율 성은 0.8973 , 규모의 효율성은 0.7394 이다. 비효 율성의 원인은 기술효율성과 규모의 효율성에
의한 것이며, 이는 기업영세성의 문제점과 기술 인력부족 등으로 해석될 수 있다. 위의 표를 기 준으로 아래〈그림 2〉에서는 $\mathrm{Y}$ 축은 효율의 정 도를 $0 \sim 1$ 까지 0.1 단위로 표시하여 각 $\mathrm{DMU}$ 를 그래프로 도식화하였다.

기술효율성의 '효율적' 또는 '준 효율적' 으로 나타낸 업체는 $41.5 \%$ 로 나타났으며, 나머 지가 '약 비효율적' 또는 '비효율적'으로 나타났 다. 순수기술효율성은 $70.8 \%$ 의 업체가 '효율적' 또는 '준 효율적'으로 나타나고 있으며, 규모의 효율성은 $50 \%$ 의 비율로 절반씩 나타났다3).

또한 본 연구는 투입지향 모형으로 투입 요소

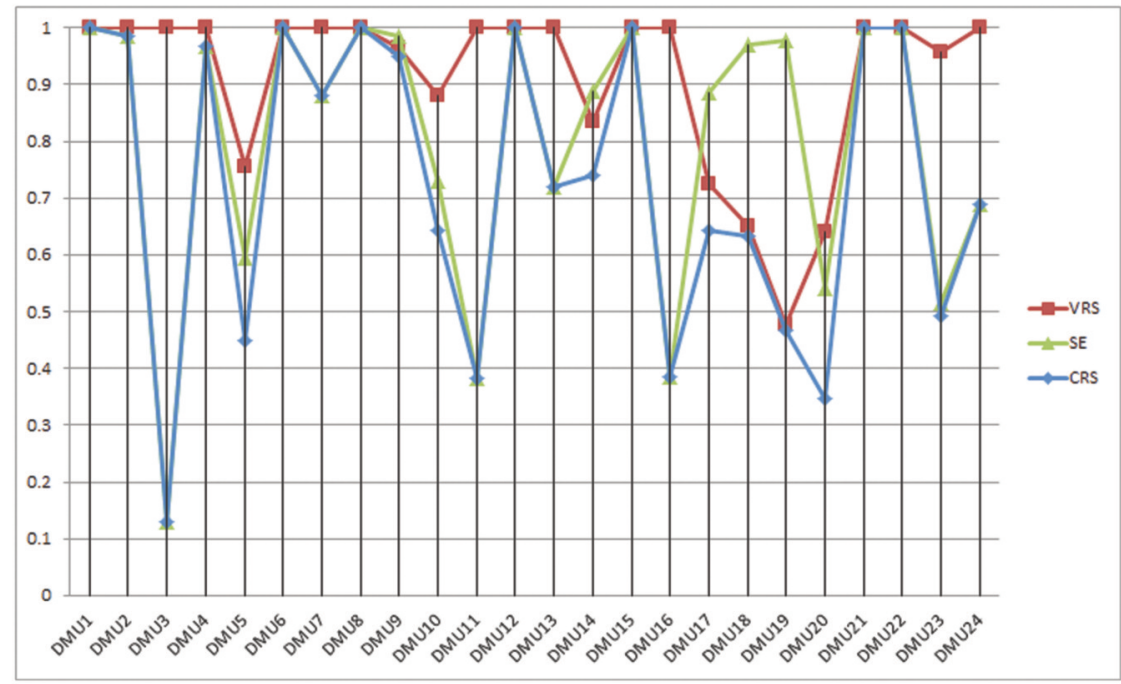

〈그림2〉선박기관 수리업체의 DEA 분석결과

〈표 8 〉비효율적인 업체의 효율성 달성을 위한 투입량 절감 목표치

\begin{tabular}{c|c|c|c|c}
\hline \multirow{2}{*}{ 업체명 } & 기술자수 & 공장규모 & 인건비총액(월) & $\begin{array}{c}\text { 월 별 재료 및 } \\
\text { 재화 구입비 }\end{array}$ \\
\cline { 2 - 5 } & 목표치(\%) & 목표치(\%) & 목표치(\%) & 목표치 $(\%)$ \\
\hline DMU5 & 75.5 & 75.5 & 60.3 & 13.8 \\
\hline DMU9 & 64.6 & 96.6 & 96.6 & 96.6 \\
\hline DMU10 & 82.2 & 66.6 & 88.2 & 88.2 \\
\hline DMU14 & 83.5 & 73.0 & 73.8 & 83.5 \\
\hline DMU17 & 61.7 & 72.6 & 72.6 & 41.3 \\
\hline DMU18 & 65.2 & 65.2 & 65.2 & 52.1 \\
\hline DMU19 & 39.9 & 47.7 & 47.7 & 28.5 \\
\hline DMU20 & 64.0 & 64.0 & 34.4 & 50.3 \\
\hline DMU23 & 95.8 & 49.1 & 95.8 & 95.8 \\
\hline
\end{tabular}

$-60-$ 
변화를 통해 비효율적인 업체가 효율성을 달성 하기 위해 투입요소들의 절감목표치를〈표 8〉 에 나타내었다. 〈표 8〉에서 언급하고 있는 9개 기업들은 모두 PTE가 ' 1 '이하인 업체들로서 투입요소에 대한 목표치를 달성하여 효율성을 높일 수 있을 것으로 판단된다.

\section{2. 순위합검증 ${ }^{4}$}

본 연구의 결과가 두 그룹 간의 효율성의 차이 가 우연에 의한 것인지 통계적으로 유의한 것인 지를 파악하기 위해 두 그룹간의 효율성 차이가 존재하는지를 통계적으로 검증해 볼 필요가 있 다. 그룹을 나누기 위해 효율적으로 나타난 기업 과 비효율적으로 나타난 기업을 나누어 분석해 보니 효율적으로 나타난 기업에 주식회사가 많 이 포함되어 있다. 따라서 그룹을 주식회사와 개 인회사 두 그룹으로 분류하여 주식회사 그룹은 그룹 1 로, 개인회사 그룹은 그룹 2로 표기하여 순 위합 검증을 실시하였다. 주식회사가 개인회사보 다 더 효과적으로 투입요소를 투입하고 있는지를 검증하기 위해 다음과 같은 가설을 설정하였다.
귀무가설 $\left(H_{0}\right)$ : 그룹 1 과 그룹 2의 효율성 평균 값은 차이가 없다.

대립가설 $\left(H_{1}\right)$ : 그룹 1 과 그룹 2의 효율성 평균 값은 차이가 있다.

〈표 9〉, 〈표 10〉은 앞에서 분석된 두 그룹의 효율성 평가 결과를 바탕으로 통계적으로 유의 성을 검정한 순위합검 증 결과이다. MannWhitney test표에서는 각 $\mathrm{DMU}$ 의 데이터에 순위 를 매겨서 그 순위의 평균과 순위합 결과를 보여 주고 있으며, $\mathrm{CRS}$ 상의 그룹 1(주식회사)의 평균 순위는 18.50 이고, 그룹 2(개인회사)의 평균 순 위는 9.5이다. Z통계량에 대한 근사 유의확률(양 측 $)=0.003<0.05$ 이므로 평균값에 차이가 없다는 귀무가설은 기각되었다. VRS상의 그룹 1 의 평 균 순위는 16 이고, 그룹 2 의 평균 순위는 10.75 로 서 이 역시 Z통계량에 대한 근사유의확률(양측) $=0.049<0.05$ 로서 평균값에 차이가 없다는 귀무 가설은 기각되었다. 마지막으로 $\mathrm{SE}$ 상의 그룹 1 의 평균 순위는 17.88 이며, 그룹 2의 평균순위는 9.81 로서 Z통계량에 대한 근사유의확률(양측)=

〈표 9〉Mann-Whitney Test

\begin{tabular}{c|c|c|c|c}
\hline \multirow{2}{*}{ 구 분 } & 그룹 & $\mathrm{N}$ & 평균순위 & 순위합 \\
\hline \multirow{3}{*}{ CRS } & 1.00 & 8 & 18.50 & 148.00 \\
\cline { 2 - 5 } & 2.00 & 16 & 9.50 & 152.00 \\
\cline { 2 - 5 } & 합계 & 24 & 16.00 & 128.00 \\
\hline \multirow{3}{*}{ VRS } & 1.00 & 8 & 10.75 & 172.00 \\
\cline { 2 - 5 } & 2.00 & 16 & 17.88 & 143.00 \\
\hline \multirow{3}{*}{$\mathrm{SE}$} & 합계 & 24 & 9.81 & 157.00 \\
\cline { 2 - 5 } & 1.00 & 8 & & \\
\cline { 2 - 5 } & 2.00 & 24 & & \\
\hline
\end{tabular}

3) Ray and Bhadra(1993)는 각 효율성의 정도가 1 일 때는 효율적(not violated), $0.9 \sim 1.0$ 미만은 준효율적(weakly violated), $0.7 \sim 0.9$ 미만은 약효율적(moderately violated), 마지막으로 0.7 미만은 비효율적(strongly violated)으 로 효율성의 정도를 크게 4가지로 구분하였다.

4) 순위합 검증이란 데이터의 순위를 이용하여 검증하는 비모수적 방법 가운데 하나이다. 두 그룹에 속하는 서 로 독립적인 데이터가 주어졌을 때, 두 그룹이 동일한 모집단에 속하는지 혹은 두 그룹의 효율성이 값이 동일 한 분포를 따르는지 여부를 귀무가설로 검증하는 것이다. 즉, 비교하는 두 그룹이 위치만 다를 뿐 같은 분포 를 하고 있다고 가정을 하고 두 그룹의 중앙값의 차이가 0인지 여부를 검증하는 방법이다(박만희, 2008). 
〈표 10〉검정 통계량b

\begin{tabular}{c|c|c|c}
\hline 구 분 & CRS & VRS & SE \\
\hline Mann-Whitney의 U & 16.000 & 36.000 & 21.000 \\
\hline Wilcoxon의 W & 152.000 & 172.000 & -2.666 \\
\hline$Z$ & -2.976 & -1.971 & .008 \\
\hline 근사 유의확률(양측) & .003 & .049 & .007 \\
\hline $\begin{array}{c}\text { 정확한 유의확률 } \\
{[2 *(\text { 단측 유의확률)] }}\end{array}$ & .002 & .093 & $\begin{array}{c}\text { 귀무가설 } \\
\text { 기각 }\end{array}$ \\
\hline 가설채택 & $\begin{array}{c}\text { 귀무가설 } \\
\text { 기각 }\end{array}$ & $\begin{array}{c}\text { 귀무가설 } \\
\text { 기각 }\end{array}$
\end{tabular}

*0.05\% 신뢰수준에서 만족함.

$0.008<0.05$ 로서 평균값에 차이가 없다는 귀무가 설을 기각함으로써 통계적 검정 결과를 바탕으 로 유의수준 $5 \%(\alpha=0.05)$ 에서 가설을 검정한 결 과 그룹 1 과 그룹 2 의 효율성 평균값은 기술적 효율성, 순수기술효율성, 규모의 효율성 모두에 서 유의한 차이가 있음을 알 수 있었다.

\section{3. 효율적인 DMU와 비효율적 DMU의 경영실태 분석}

순위합검증 결과값이 유의미하게 도출됨으로
써 주식회사와 개인회사의 차이가 존재하는 것 으로 밝혀짐에 따라 주식회사 중 효율적 DMU 2 개 업체를 선정하고 비효율적으로 나타난 개인 업체 중 6 개 업체를 선정하여 투입된 변수와 변 수로서 투입되지 않았지만 경영적 평가요소를 선정하여 두 그룹을 실태조사하였다. 투입된 변 수를 중심으로 노동, 자본, 기술로 나누어 재방 문과 기존의 FGI 자료를 활용하여 비교해 보았 다〈표 11〉.

〈표 11 〉 투입된 변수를 중심으로 한 효율적 DMU와 비효율적 DMU비교

\begin{tabular}{|c|c|c|c|}
\hline 구분 & \multicolumn{2}{|c|}{$\begin{array}{c}\text { 효율적으로 나타난 } \mathrm{DMU} \\
\text { 2개 업체 }\end{array}$} & $\begin{array}{l}\text { 비효율적으로 나타난 DMU } \\
\text { 6개 업체 }\end{array}$ \\
\hline \multirow{3}{*}{ 노동 } & $\begin{array}{l}\text { 효율적 } \\
\text { DMU1 }\end{array}$ & $\begin{array}{l}\text { 총 종업원 수 } 46 \text { 명중 } 20 \text { 명 } \\
\text { 기술 근로자 비율 } 43 \%\end{array}$ & \multirow{2}{*}{$\begin{array}{l}\text { 6개 업체의 총 종업 원 수 대비 기술직 근로자수 } \\
\text { 비율의 평균은 } 82.76 \% \text { 로 나타남 }\end{array}$} \\
\hline & $\begin{array}{l}\text { 효율적 } \\
\text { DMU2 }\end{array}$ & $\begin{array}{l}\text { 총 종업원 수 } 92 \text { 명중 } 56 \text { 명 } \\
\text { 기술 근로자 비율 } 52 \%\end{array}$ & \\
\hline & \multicolumn{3}{|c|}{$\begin{array}{l}\text { *효율적으로 나타난 } 2 \text { 개 업체에서는 기술자외에 연구분야, 영업분야에 많은 인력을 투입하고 있 } \\
\text { 었고 일용직 근무자 채용이 적었던 반면, 비효율적으로 나타난 업체의 경우, } 6 \text { 개 업체 모두 일용 } \\
\text { 직 근무자를 채용하고 있었고, 연구분야나 해외 영업 방면으로는 전무하였다. }\end{array}$} \\
\hline \multirow{3}{*}{ 자본 } & 효율적 & $\begin{array}{l}\text { 공장규모:250평 } \\
\text { 고정자산 구입총액: } 5 \text { 억원 } \\
\text { 월 인건비총액: } 1.2 \text { 억 } \\
\text { 월별 재료 구입비:4.5억 }\end{array}$ & \multirow{2}{*}{$\begin{array}{l}\text { 공장규모:평균 } 84 \text { 평 } \\
\text { 고정자산구입총액: 평균 } 8 \text { 천6백 만원 } \\
\text { 월인건비총액: 평균 2천3백 만원 } \\
\text { 월별재료구입비: 평균3천6백 만원 }\end{array}$} \\
\hline & $\begin{array}{l}\text { 효율적 } \\
\text { DMU2 }\end{array}$ & $\begin{array}{l}\text { 공장규모:2000평 } \\
\text { 고정자산구입총액:6억 } \\
\text { 월 인건비총액:4억 } \\
\text { 월별 재료 구입비: } 1 \text { 억 }\end{array}$ & \\
\hline & \multicolumn{3}{|c|}{$\begin{array}{l}\text { *비효율적으로 나타난 업체의 경우 } 4 \text { 개 업체가 임대의 형태로 업체를 운영하고 있으며, 고정자산 } \\
\text { 에 해당하는 기계나 설비의 경우도 적었다. }\end{array}$} \\
\hline \multirow{2}{*}{ 기술(1) } & $\begin{array}{l}\text { 효율적 } \\
\text { DMU1 }\end{array}$ & $\begin{array}{l}\text { 주거래 업체 수: } 100 \text { 여곳 } \\
\text { 연간 수리건 수: } 250 \text { 건 }\end{array}$ & \multirow{2}{*}{$\begin{array}{l}\text { 주거래 업체 수: 평균 } 77 \text { 여곳 } \\
\text { 연간 수리건 수:평균 } 113 \text { 건 }\end{array}$} \\
\hline & $\begin{array}{l}\text { 효율적 } \\
\text { DMU2 }\end{array}$ & $\begin{array}{l}\text { 주거래 업체 수: } 50 \text { 여곳 } \\
\text { 연간 수리건 수: } 250 \text { 건 }\end{array}$ & \\
\hline
\end{tabular}


노동의 측면에서 비교해 보았을 때, 효율적 업 체로 나타난 2개 업체의 전체 근로자 중 기술 근 로자는 각각 $43 \%$ 와 $52 \%$ 로 나타난 반면, 비효율 적으로 나타난 DMU 6개 업체는 $82.76 \%$ 로 기술 직의 비율이 월등히 높았다. 규모가 작은 개인 업체일수록 인력부족에 시달리게 되어 기술 근 로자가 사무직 등과의 겸직하는 비율이 높다. 반 면 효율적으로 나타난 업체에서는 사무직 근로 자와 기술 근로자의 업무 세분화가 잘 이루어져 있다고 할 수 있다. 또한 효율적으로 나타난 업 체의 경우 연구 분야와 영업 분야에도 별도의 인 원을 투입하여 효율성 증대에 기여하고 있었음 을 알 수 있었다.

자본의 측면에서는 효율적으로 나타난 업체 로 나타난 업체의 경우에는 고정자산에 대한 투 자, 공장 규모 및 소유, 인건비 총액과 월별 재료 구입비의 규모가 월등한 것으로 나타났다. 두 곳 모두 공장을 자가 소유하고 있었으며 공장 설비 에 대한 지속적인 투자가 이루어지고 있었다. 반 면, 비효율적으로 나타난 $\mathrm{DMU}$ 에서는 공장을 임대조건으로 사용하고 있는 업체가 4군데에 달 했고, 고정자산 또한 공장 면적에 대한 부담과 구입금액에 대한 부담으로 많은 설비를 하지 못 하고 있는 것으로 추정되었다.

기술측면의 경우는 연간 수리건수를 주거래 업체의 수로 나누어 추정해 보았다. 효율적 $\mathrm{DMU}$ 의 경우 업체수당 수리 건 수가 3.6건인 것 에 반해 비효율적으로 나타난 업체는 평균 1.4건 으로 나타나 상대적으로 열세인 것으로 파악되 었다.

〈표 12〉에서는 투입되지 않았지만 경영적 평가 요소로서 효율성에 영향을 미치는 요소로 효율적으로 나타난 DMU에서는 조직화와 업무 세분화, 생산표준화, 근로자복지수준, 공장 내 기계배치, 사내작업환경, 업체위치와 현재 업체 가 직면하거나 앞으로 다가올 문제점 등에 대해 서 두 그룹을 비교하였다.

조직화 및 업무세분화 측면에서의 효율적으
로 나타난 업체는 두 곳 모두 전문 경영인을 도 입하여 회사경영을 하고 있었으며 조직면에서 도 수평적 분화가 잘 이루어져 있었다. 파트별 인원을 적절히 배치하여 구체적인 업무분담이 이루어져 여러 건의 공사가 가능했던 반면, 비효 율적으로 나타난 DMU에서는 소수의 인원인 관 계로 업무분담이 잘 되지 않았고, 작업에 모든 기술자들이 일괄적으로 투입되어 동시에 여러 건의 공사가 불가능한 것으로 평가되었다.

생산표준화의 측면에서 효율적으로 나타난 업체는 전사적 품질경영시스템을 도입, 시행착 오를 거쳐 표준화가 정착되어 회사 팜플렛이나 홍보용 책자에 자세히 기재되어 있었으며, 2곳 모두 ISO 인증업체이다. 비효율적으로 나타난 $\mathrm{DMU}$ 의 경우에는 경험에 의한 노하우는 있으나 경영품질을 표준화시키고 있는 곳은 2 곳에 불과 하였고, 팜플렛이나 홍보용 책자가 있는 경우도 1 곳에 불과하였으며, $\mathrm{ISO}$ 인증 업체 또한 6 곳 중 2곳에 그쳤다.

근로자 복지수준은 두 그룹 모두 탈의실과 샤 워시설을 확보하고 있었다. 또한 모두 주 5일제 근무 보장은 되지 않았지만 효율적 $\mathrm{DMU}$ 는 휴 가를 실시하는 업체가 대다수였으며 비효율적 인 DMU의 경우에는 일용직 근무자를 채용하고 있는 곳이 많아 근로복지 수준이 미흡하였다.

비효율적으로 나타난 DMU의 공장 설비배치 는 다수의 업체가 협소한 공간, 독립된 공장부지 확보의 어려움으로 인해 동선을 고려하지 않고 구입 순차적으로 배치를 하고 있었다. 이는 작업 환경 여건에도 불리하게 작용하여 주차 공간 확 보에 어려움, 용접 공간 미확보로 인해 도로와 인접한 공장 입구쪽에서 용접을 하고 있어 위험 요소로 작용하고 있었다.

수리조선업체가 직면해 있는 문제점으로는 각종 세금에 대한 부담, 정부지원혜택 전무, 자 본문제, 근로자 고용문제, 미래에 대한 불확실 등으로 두 그룹 모두 유사한 답변을 하였으며 효 율적으로 나타난 업체 2곳 모두 중국으로 이전 
〈표 12 〉 투입되지 않았던 변수를 중심으로 한 효율적인 DMU와 비효율적인 DMU 비교

\begin{tabular}{|c|c|c|}
\hline 구 분 & $\begin{array}{c}\text { 효율적으로 나타난 주식회사 } \\
\text { 2개업체 } \\
\end{array}$ & $\begin{array}{c}\text { 비효율적으로 나타난 개인회사 } \\
\text { 6개업체 } \\
\end{array}$ \\
\hline \multirow{2}{*}{$\begin{array}{l}\text { 조직화 및 } \\
\text { 업무세분화 }\end{array}$} & $\begin{array}{l}\text { ·전문 경영인 도입 } \\
\text { ·수평적 분화가 이루어져 있음 }\end{array}$ & $\begin{array}{l}\text { 조직화는 이루어져 있으나 소수의 인원인 관 } \\
\text { 계로 업무분담이 잘 되지 않음. }\end{array}$ \\
\hline & $\begin{array}{l}\text { ·파트별 인원배치 } \\
\text { ·구체적인 업무분담(여러건의 공사 가능) }\end{array}$ & $\begin{array}{l}\text { 작업에 모든 기술자들이 일괄적으로 투입 } \\
\text { (1개 공사가 시작되면 다른 공사 진행 불가) }\end{array}$ \\
\hline 생산표준화 & $\begin{array}{l}\text { · 전사적 품질경영시스템 } \\
\text { · 시행착오를 거쳐 표준화 정착. } \\
\text { · 회사 내부 지침 마련 } \\
\text { · 팜플렛이나 홍보용 책자에 자세히 기재. } \\
\text { · 2곳 모두 ISO 인증업체 }\end{array}$ & $\begin{array}{l}\text {. 영업상담시 작업시간 조율, 경험에 의한 노하 } \\
\text { 우는 있으나 표준화 시키고 있는 곳은 } 6 \text { 곳 중 } \\
2 \text { 곳에 불과하였음. } \\
\text { · 팜플렛이나 홍보용 책자 발간한 곳 } 1 \text { 곳에 불과 } \\
\text { - ISO인증 업체: } 2 \text { 개 업체 }\end{array}$ \\
\hline 근로자 복지수준 & $\begin{array}{l}\text {. 샤워실, 탈의실, 휴게실, 각종 자판기보유 } \\
\text {. 주5일제 근무 보장 안되지만 연차 및 월차 사 } \\
\text { 용가능, 주말 휴무 보장 }\end{array}$ & $\begin{array}{l}\text { 6곳 모두 탈의실, 샤워시설 확보 } \\
\text { · 휴게실 확보된 업체2곳 } \\
\text { · 연차 및 월차, 주일 휴무 보장 안됨 } \\
\text { · 일용직 근무자 다수 }\end{array}$ \\
\hline 공장 내 기계배치 & · 작업 동선을 고려한 배치 & $\begin{array}{l}\text { 협소한 공간내부로 인해 구입 순차적으로 배 } \\
\text { 치하거나 동선을 고려하지 않음 }\end{array}$ \\
\hline \multirow[t]{2}{*}{ 사내 작업환경 } & $\begin{array}{l}\text { - } 2 \text { 곳 모두 독립된 건물을 소유하고 있었고 } 1 \text { 층 } \\
\text { 과 } 2 \text { 층을 공장과 사무실을 완전 분리하여 소 } \\
\text { 음, 유해 요소의 차단이 잘되어있었음. } \\
\text { · 근로자의 동선 또한 유기적인 설계에 의해 짜 } \\
\text { 여져 작업 시 서로 영향을 주지 않았음 } \\
\text { · 적정부지 확보를 통해 주차시설 및 적재장소 } \\
\text { 가 많음 }\end{array}$ & $\begin{array}{l}\text { ·협소한 공간으로 인해 용접공간 미확보 } \\
\text { · 동선확보가 되지 않아 작업시 불편 } \\
\text { · 일반주택을 개조하여 사용하는 업체가 다수 } \\
\text { · 공장과 사무실을 분리하고 있는 형태였지만 } \\
\text { 유해요소에 차단이 미약함 } \\
\text { · 주차부지 부족으로 인해 공장안에 차량이 주 } \\
\text { 차되어 굉장히 위험함. }\end{array}$ \\
\hline & ·2곳 모두 CLEAN작업장 선정(노동부) & . 6 개 업체 중 1 개 업체만 CLEAN 작업장 \\
\hline 문제점 & $\begin{array}{l}\text { · 정부지원혜택 전무 } \\
\text { · 미래 불확실에 대한 두려움 } \\
\text { · 2곳 모두 중국으로 이전 검토 } \\
\text { · 근로자 고용문제 }\end{array}$ & $\begin{array}{l}\text { ·각종 세금에 대한 부담 } \\
\text { · 정부지원혜택 전무 } \\
\text { · 자본문제(임금, 대출, 어음 등) } \\
\text { · 근로자 고용문제 }\end{array}$ \\
\hline
\end{tabular}

을 검토하고 있는 것으로 나타났다. 이는 상대적 으로 싼 임금, 중국 조선경기 부양을 새로운 경 영전환으로 활용하기 위함이다.

자본문제에 있어서는 비효율적으로 나타난 $\mathrm{DMU}$ 에서 상대적으로 세금, 임금지급, 은행권 대출, 결제 어음 등의 문제로 어려움을 느끼고 있었다. 그 밖에 공공적으로 안고 있는 문제는 직업인식의 변화로 수리조선업체에서는 고용문 제에도 고충을 겪고 있었는데 눈앞의 계약도 당 장 대체할 인력부족으로 놓치는 경우도 있었으 며, 외국인 근로자에 대한 고용 또한 쉽지 않고, 이에 대한 정부지원혜택이 전무하다고 응답해 정부의 적극적인 정책지원이 필요한 것으로 판 단된다.

\section{$\mathrm{V}$. 결 론}

본 연구는 부산 영도구에 위치한 수리조선 산 업내의 선박기관 수리기업 경영효율성을 분석 하였다. DEA 분석결과, 총 24 개의 DMU중 7 개 의 업체가 효율적인 업체로 나타났고, 17 개 업체 가 비효율적인 것으로 분석되었다. 효율적인 $\mathrm{DMU}$ 로 나타난 7개 업체의 경우, 투입요소가 나 머지 17 개 업체에 비해 효과적으로 투입되어 효 율적인 산출량을 얻고 있는 것으로 추정된다. 반 면 나머지 비효율적으로 나타난 17 개의 업체는 규모의 체증이 나타난 14 개 기업과 규모의 체감 이 나타난 3 개 업체였다.

규모의 체증이 나타난 14 개 업체의 경우, 규모 
의 경제 실현 즉, 과감한 기업투자와 기업 확장 을 통해 기업의 효율성을 증대시킬 수 있다. 하 지만 현실적으로 영세기업이 다수를 차지하는 선박기관 수리기업에서는 기업간 협업, 공동사 업, 업무제휴 등을 통해 점진적 규모 확대를 이 루는 방안을 고려해 볼 필요가 있다. 또한 동남 권 조선산업 클러스터와 지역 내 산학협력 시스 템을 활용하여 연구기관과 대형조선소와의 기 술제휴, 가격 경쟁력 확보를 통해 효율성을 극대 화시킬 수 있을 것이다.

규모의 체감이 나타난 3 개 업체는 규모의 확 대보다는 투입요소의 통제와 경영시스템의 개 선을 통해 업체효율성을 높여가야 할 것으로 분 석되었다. 하지만 3 개 업체 모두 주식회사의 형 태로 초기 주식회사 전환과정에서의 투자금이 아직 회수되지 못한 점과 생산규모의 증가에 따 라 오히려 의사전달 및 의사결정체제가 복잡해 져 경영상의 비효율이 규모의 체감 원인으로 지 적할 수 있다.

위의 결과를 활용하여 주식회사와 개인회사 로 그룹을 나누어 효율성의 차이가 유의한지 여 부를 검증하기 위해 효율성 평균값의 차이에 따 른 귀무가설과 대립가설로 나누어 검증하였다. 그 결과, 주식회사와 개인회사의 효율성 평균값 은 기술적 효율성, 순수기술효율성, 규모의 효율 성 모두에서 효율 평균값의 차이가 없을 것이라 는 귀무가설을 기각하여 유의한 차이가 있는 것 으로 검증되었다.

마지막으로 사후검정에서 효율적으로 나타난 2 개의 주식회사와 비효율적으로 나타난 개인 회 사 6개 DMU를 무작위로 선정하여 투입되었던 변수인 노동, 자본, 기술 3 가지 변수를 중심으로 비교분석하였고, 투입되지 않았지만 경영성과 에 영향을 미칠 수 있는 요소로서 조직화 및 업 무세분화, 생산표준화, 근로자 복지수준, 공장 내 기계배치, 사내작업환경, 문제점에 대해 업체 재방문 및 인터뷰 내용을 바탕으로 분석하였다.

효율적 $\mathrm{DMU}$ 의 경우, 비효율적 $\mathrm{DMU}$ 에 비해
기술자 외에도 연구분야, 영업분야에 많은 인력 을 투입하고 있었고 전문경영인을 도입하여 업 무분화가 잘 이루어져 있었다. 또한 생산표준화 를 구축하여 직원들의 효율적인 업무역량을 도 모하였으며, 사내작업환경의 쾌적함과 더불어 근로자의 복지 수준 향상을 위해 많은 노력을 기 울이고 있었다.

이에 비해 비효율적 DMU에서는 인력부족으 로 인한 기술 근로자의 겸업, 겸직의 비율이 높 고 수리공사 중에도 일용직 근로자 채용이 많았 다. 또한 공장과 사무실을 임대로 빌려 사용하고 있는 업체가 대다수였으며 근로자의 작업환경 의 개선이 필요한 것으로 판단된다.

이와 더불어 정부의 적극적인 정책 및 지원도 필요한 것으로 사료된다. 감천항일대 수리조선 단지 조성계획의 실패를 교훈삼아 부산신항 내 수리조선단지 조성을 위해 노력해야 하며, 더불 어 수리조선 산업의 정확한 산업분류와 통계조 사를 통해 산업 발전을 강구해야 한다. 본 연구 에서는 최근 수리조선 산업에 닥친 경기불황과 경쟁업체 과다에 따른 수익성 침체, 인력부족이 라는 근원적 문제 속에서 업체의 경영성을 평가 하고 효율적인 경영 벤치마킹 유형을 제시함으 로써 비효율적으로 나타난 업체의 개선점을 도 출하였다는데 그 의의가 있다.

본 연구에서는 다음과 같은 한계점을 가진다. 첫 번째, 제한된 표본의 수와 변수로 선정된 투 입 및 산출요소로 인해 업체의 효율성 및 생산성 분석이 고정된 틀 안에서 제한적으로 이루어져 일반화에 어려움이 있다. 개인기업의 자료획득 의 어려움으로 전수조사를 실시하지 못했다.

둘째, DEA가 지니고 있는 연구 결과의 한계점 에 대해 언급하자면 상대적인 비교의 결과로써 $\mathrm{DMU}$ 집단의 절대적인 경영수준을 반영하지 못 한다는 점이다. 다시 말해 효율성 값이 '1' 로 평가 되어 상대적으로 효율성이 높은 업체로 분석되 었을지라도 해당 DMU가 경영개선의 여지가 전 혀 없는 것이 아니며, 선정된 표본 및 입력변수 
에 따라 값이 다르게 나타나기 때문이다.

\section{참고문헌}

김강정, “우리나라 호텔산업의 생산성분석”, 經營研

究, Vol.19, No.20, 2005, pp.113-133.

김 성 태, 퍼지계층분석법을 이용한 부산지역 수리조선업

의 경쟁력 제고방안에 관한 연구, 부산대학교 박사

학위논문, 2009.

박형호 - 김철 · 두진일, “부산지역 수리조선산업의

현황과 발전방안”, 지역경제 조사연구자료, 2003, p.34.

배준호, DEA분석을 이용한 특급호텔 외식사업부의 경영

효율성에 관한 연구, 경희 대학교 대학원 박사학위 논문, 2009.

서무천, 전남 수리 조선산업 경쟁력 분석, 목포대학교 대 학원 석사학위논문, 2010.

신용존 · 오진석 - 이상득, "수리조선산업을 활용한

부산신항 활성화 방안”, 한국마린엔지니어링학회

지, Vol.31, No.6, 2007, pp.810-817.
장정주, "연구논문 : 사회적기업의 경영효율성 평가 를 위한 DEA모형 도입에 관한 연구 $-\mathrm{H}$ 지역의 간병, 가사지 원업을 중심으로 -", 기업경영연구, Vol.34, 2010, pp.179-191.

정성민 · 오진석 · 송영일, "방위산업체의 효율성 및 생산성 분석”, 政策分析評價學會報, Vol.20, No.4, 2010, pp.301-331.

최민영, $\mathrm{DEA}$ 를 이용한 $\mathrm{BSC}$ 기반의 은행지점 효율성 평 가, 숭실대학교 대학원 석사학위논문, 2008

박만희, “효율성과 생산성 분석”, 한국학술정보, 2008, p.94.

Charnes, Cooper \& Rhodes, "Measuring the efficiency of the decision making unit," European journal of operational research, Vol.2, Issue 6, 1978, pp.429444.

Banker, Charnes \& Cooper, "Some models for estimating technical and scale inefficiencies in data envelopment analysis," Management Science, Vol.30, No.9, 1984, pp.1078-1092. 